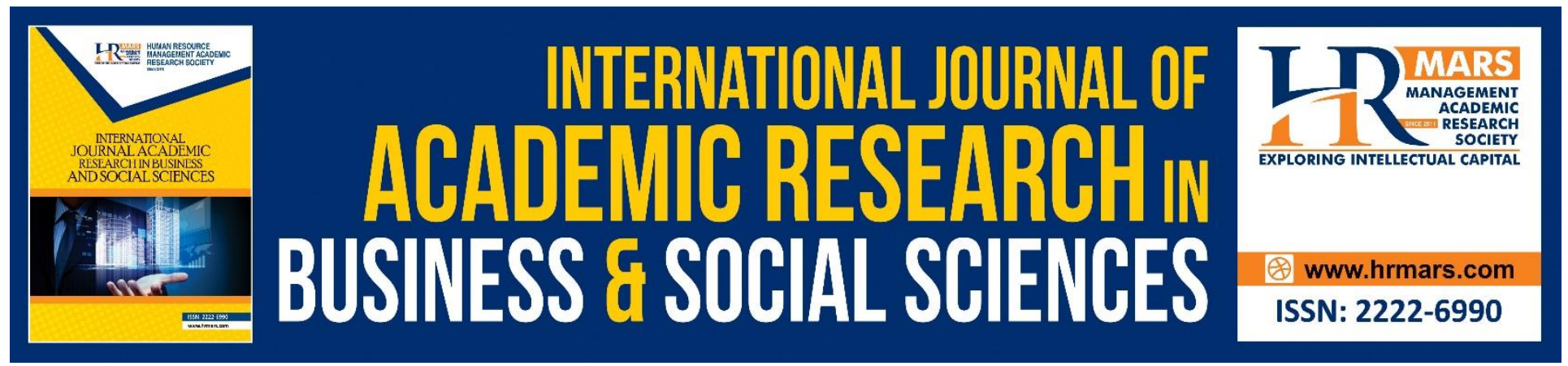

\title{
Motivation and Self-efficacy of Science Teachers in Fostering HOTS in Peninsular Malaysia
}

Nurulhuda Abd Rahman, Paramesvary A/P Perumal, Eng-Tek Ong

To Link this Article: http://dx.doi.org/10.6007/IJARBSS/v8-i12/5329

DOI: $10.6007 /$ IJARBSS/v8-i12/5329

Received: 11 Nov 2018, Revised: 16 Dec 2018, Accepted: 21 Dec 2018

Published Online: 30 Dec 2018

In-Text Citation: (Rahman, Perumal, \& Ong, 2018)

To Cite this Article: Rahman, N. A., Perumal, P. A., \& Ong, E.-T. (2018). Motivation and Self-efficacy of Science Teachers in Fostering HOTS in Peninsular Malaysia. International Journal of Academic Research in Business and Social Sciences, 8(12), 1825-1842.

\section{Copyright: (C) 2018 The Author(s)}

Published by Human Resource Management Academic Research Society (www.hrmars.com)

This article is published under the Creative Commons Attribution (CC BY 4.0) license. Anyone may reproduce, distribute, translate and create derivative works of this article (for both commercial and non-commercial purposes), subject to full attribution to the original publication and authors. The full terms of this license may be seen

at: http://creativecommons.org/licences/by/4.0/legalcode

Vol. 8, No. 12, 2018, Pg. 1825 - 1842

http://hrmars.com/index.php/pages/detail/IJARBSS

JOURNAL HOMEPAGE

Full Terms \& Conditions of access and use can be found at http://hrmars.com/index.php/pages/detail/publication-ethics 


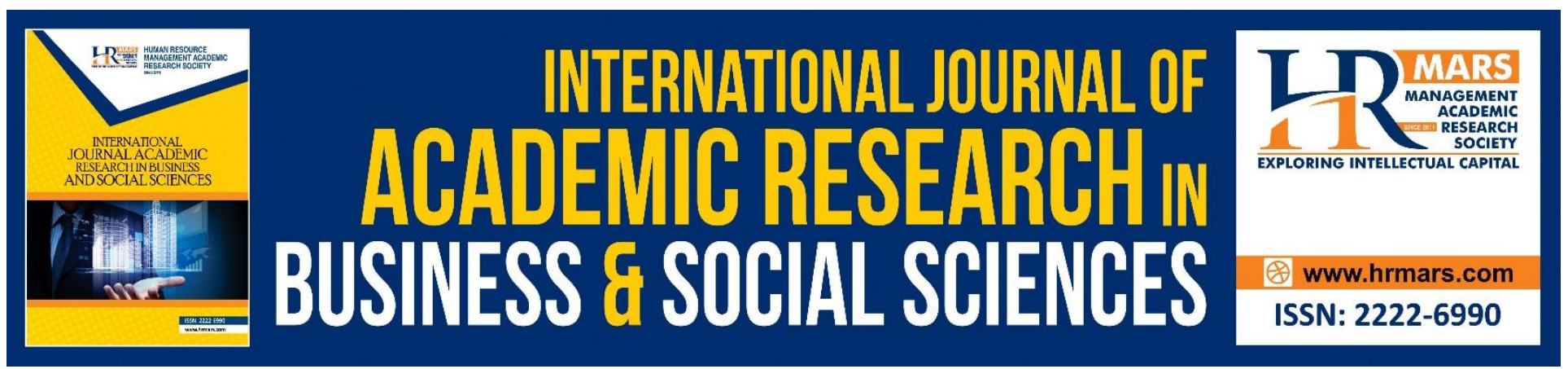

\title{
Motivation and Self-efficacy of Science Teachers in Fostering HOTS in Peninsular Malaysia
}

\author{
Nurulhuda Abd Rahman \\ Department of Physics, Faculty of Science \& Mathematics, Universiti Pendidikan Sultan Idris, \\ Tanjung Malim, Perak, Malaysia. \\ Email: nurulhuda@fsmt.upsi.edu.my \\ Paramesvary A/P Perumal \\ Department of Physics, Faculty of Science \& Mathematics, Universiti Pendidikan Sultan Idris, \\ Tanjung Malim, Perak, Malaysia. \\ Email: pam3p2004@yahoo.com

\section{Eng-Tek Ong} \\ Department of Educational Studies, Faculty of Human Development, Universiti Pendidikan Sultan \\ Idris, Tanjung Malim, Perak, Malaysia. \\ Email: ong.engtek@fpm.upsi.edu.my
}

\begin{abstract}
The aim of this study is to explore lower secondary science teachers' level of motivation and self-efficacy regarding meta-strategic knowledge, level of perceived importance, the frequency of practice and level of confidence in fostering higher-order thinking skills (HOTS) in teaching science. A survey design was employed and data were gathered using a questionnaire as an instrument. A total of 220 participants were sampled using stratified random sampling in Peninsular Malaysia. Findings indicate that the motivation and self-efficacy of the teachers in fostering HOTS during science teaching are at moderately high level. Significant positive relationships among perceived importance, frequency of practice and level of confidence were observed. Expertise in meta-strategic knowledge and an inclusive approach aimed at fostering HOTS during science lessons are the necessary ingredients in science teaching in contemporary schooling. In conclusion, this study affirms that the in-service science teachers' motivation and self-efficacy are moderately high and significantly related to fostering HOTS.
\end{abstract}

Keywords: Motivation, Self-Efficacy, Fostering HOTS, Science Education 


\section{Introduction}

Higher-order thinking skills (HOTS) is an important attribute in intellectual development, which includes knowledge management, social and creative meta-cognitive competencies and values (Chinedu, Kamin, \& Olabiyi, 2015; King, Goodson, \& Rohani, 2011). Therefore, teachers play a crucial role in nurturing HOTS among students. The mandate bestowed on teachers has been discussed in Malaysian education literature ever since the introduction of creative and critical thinking through the Integrated Curriculum for Secondary School (ICSS) into the science syllabuses (Curriculum Development Centre, 2005). The need to foster HOTS is further emphasized in the Malaysia Education Blueprint 2013-2025 (Kementerian Pendidikan Malaysia, 2013a) which specifically highlights acquiring HOTS as the nation's 'Student Aspiration'.

The transformation towards the promotion of Higher Order Thinking contributes immensely to the change of instructional strategies practised by teachers in the classrooms. Hence, a paradigm shift from the content-oriented instruction to that of a process-oriented instruction is warranted and such a shift is highly dependent on teachers' pedagogical knowledge and belief about teaching and learning (Zohar, 2006). Such transition demands not only an in-depth subject matter knowledge but also a sound pedagogical knowledge to develop HOTS - both as a general skill and also in the context of subject content (Barak \& Shakman, 2008). Teachers' competence and approach to teaching determine students' ability to think (Raisa et al., 2014). The teachers' values, interest and disposition towards fostering HOTS can also influence students' thinking and learning (Raisa et al., 2014). If a teacher aims to prepare students at a higher level of cognitive thinking, he/she must first incorporate higher level thinking in his/her instructional practices (Nooraini Othman \& Khairul Azmi Mohamad, 2014; Raisa et al., 2014). Teaching HOTS requires time and persistent effort by the teachers that may be contextually strengthened and conceptually analysed (Sukla \& Dungsungneon, 2016). There is a crucial link between teachers' competence in using the instructional method and tools to foster HOTS and its implementation. The link is identified as intrinsic work motivation (knowledge, importance) and self-efficacy (confidence, practice) of the teachers.

Therefore, the objective of this paper is to understand teachers' motivation and self-efficacy in fostering HOTS by focusing on

- Knowledge of the instructional methods, activities and techniques (meta-strategic knowledge) to foster HOTS.

- The degree of perceived importance of the instructional methods, activities and techniques to foster HOTS as perceived by teachers.

- The frequency of the instructional methods, activities and techniques to foster HOTS which were put into practice.

- The level of perceived confidence in implementing the instructional methods, activities and techniques to foster HOTS.

- The relationship between meta-strategic knowledge, degree of perceived importance, level of perceived confidence and the frequency of these instructional methods, activities and techniques to foster HOTS which were put into practice. 


\section{LITERATURE REVIEW}

This study draws upon two theoretical perspectives to capture the in-service science teachers' perspective about fostering HOTS in teaching science at lower secondary. The first theoretical perspective arises from the teacher motivation and self-efficacy literature, a line of inquiry in which there has been a considerable amount of research in science teacher education. The second theoretical perspective, one which has a much shorter history within science teacher education is that of HOTS, particularly in fostering HOTS within the context of teacher teaching.

\section{Motivation and Self-Efficacy}

Motivation is defined as the process that initiates, directs and maintains behaviour (Deci \& Ryan, 1985). With regard to learning, motivation to learn can be defined as "the degree to which students invest attention and effort in various pursuits, which may or may not be the ones desired by their teachers" (Brophy, 2010, p.3). Motivation has been an essential and widely studied concept in educational research because of its impact on academic functioning and success (Bedel, 2015; Lens, Deci \& Vansteenkiste, 2006). For instance, learning outcomes and achievement are very much affected by motivation (Brophy, 2010; Vedder-Weiss \& Fortus, 2013).

Motivation theorists often categorise motivation into two different categories: extrinsic and intrinsic motivation as the different causes that lead to action (Deci \& Ryan, 1985; Scott, Farh, \& Podsakoff, 1988). Intrinsic motivation, which refers to the motivation to do something due to inherent satisfaction (Deci, 1972; Ryan \& Deci, 2000), has been known as one critical factor that influences the learning process (Ryan \& Stiller, 1991). Given that intrinsic motivation is an important motivator that affects learning, adaptation, and competencies, it is thus a necessity for human development (Deci \& Ryan, 1985). An individual engages in intrinsically motivated behaviour in order to feel competent and self-determining. Innate motivation depends on the innate need for selfdetermination to facilitate the development of competency (Lens, Deci \& Vansteenkiste, 2006). Thus, self-determination is central to intrinsically motivated behaviour and it is the essence of a more recent educational term, heutagogy where "the focus is on what and how a learner wants to learn, not on what is to be taught" (Hase \& Kenyon, 2015, p. 8). Extrinsic motivation, by contrast, refers to doing something because it leads to a valued outcome such as improved academic performance, rewards, and better job prospects (Deci, 1972). Extrinsic motivators include anything related to work, such as promised rewards, praise, and deadlines (Amabile, 1993).

The most prevalent theoretical approach to understanding academic motivation adopted by educational researchers in Self-determination Theory (SDT) (Bedel, 2015) is that intrinsic motivation plays an important role in SDT. When an individual experiences self-determination, he/she is intrinsically motivated (Deci \& Ryan, 1985). SDT focuses on competence, relatedness and autonomy as innate needs that must be met for optimal human functioning. Need for competence is a need to gain mastery of task and different skills encountered in environment as he/she upholds self-worth and positive self-perception. Need for relatedness refers to the desire for affiliation and approval, while need for autonomy refers to the need to feel capable of making choices and decision. Deci and Ryan (1985) posit that when people are able to meet these three needs (i.e., competence, relatedness, and autonomy), they become self-determined and are able to be intrinsically motivated to pursue the things that interest them. 
Meanwhile, efficacy refers to a person's possession of the knowledge and skills necessary to perform certain behaviour. The efficacy theory entails that people are aware not only of how they motivate themselves, but also of how they act, think and feel (Ritter, Boone, \& Rubba, 2001). Therefore, it follows that self-efficacy, an important concept that was brought forward by Bandura (1997) in his Social Learning Theory (i.e., Social Cognitive Theory), is the judgment of an individual concerning his or her ability to organise and achieve a given task (Ritter et al., 2001). In other words, self-efficacy perception reflects individuals' judgment about how well they are able to perform the actions required to cope with a given situation. In this respect, self-efficacy refers to a person's belief in his/her ability to perform the actions or skills, and such beliefs impact the ways that individuals feel, think, motivate themselves, and act (Ritter et al., 2001). Research indicates that learners are motivated to learn if they have positive self-efficacies (e.g., they believe that they can be successful) (Maddux, 1995). As Kauchak and Eggen (1997) express, self-efficacy beliefs are an important factor in an individual's motivation for learning.

Teachers' self-efficacy is the teachers' belief (or confidence) about their capacity to organise and execute to accomplish specific task within a given context (Bandura, 1997; Stajkovic, 2016). Student growth contributes immensely to the understanding of teaching practice (Stajkovic \& Luthans, 1998). Grounded in Bandura's Social Cognitive Theory (SCT), teachers' self-efficacy explains about their personal ability to influence student learning and also the results of specific instructional intervention (Stajkovic \& Luthans, 1998). As the efficacy belief is the best indicators of future action or decision of all aspects in an individual's life (Stajkovic, 2016), having a strong positive teaching selfefficacy belief is considered to be a valuable teacher characterisation.

Stajkovic (2016) claims that self-efficacy makes an important contribution towards motivation. Hence, self-efficacy is considered as a positive factor to motivational theory and practice. Work motivation process involves teachers evaluating and integrating information about their perceived capabilities before selecting their choices and initiate their effort. It implies that the initiation of work behaviour is determined by self-efficacy. Bandura highlighted three dimensions of self-efficacy that enhance human performance: magnitude, strength and generality. Magnitude refers to task difficulty and complexity an individual believes he/she is capable of executing. Strength, the second dimension, refers to the evaluation about the strengths/weaknesses of the self-efficacy magnitude. Whereas, the third dimension, generality, is the belief of capability to perform a specific task (domain specific cognition) or a wide variety of tasks. Self-efficacy determines whether an individual's work behaviour will be initiated, the amount of effort that will be exerted and the length of that effort that will be sustained.

Additionally, Bandura identified four major categories of experiences and sources of information that determine self-efficacy belief (Bandura, 1997): (1) Mastery experiences: Experiencing success should raise one's confidence that one will be able to accomplish similar tasks whereas repeated failures may diminish one's confidence in success; (2) Vicarious experiences: Observing similar others' successful performance can raise observers' self-efficacy because people are inclined to believe they too are more likely to succeed in the task if it is observed that others can perform new or challenging tasks successfully; (3) Verbal and social persuasions: Encouragement from teachers and other students along with evaluative, positive feedback about performance may raise students' confidence in accomplishing a task in a related domain; and (4) Psychological and 
affective states: Positive reactions, such as being in a good mood, may raise self-efficacy beliefs whereas negative emotional reactions, such as anxiety or stress, may lower self-efficacy beliefs. Nevertheless, it is crucial that the acknowledgement of the relevant determinants should be based on how they correspond with the cognitive process. Education research literature reveals that the first determinant, mastery experiences such as succeeding on a challenging task, provides the strongest information for the development of teacher self-efficacy (Bostan, Sahin, \& Ertepinar, 2015).

\section{Higher-Order Thinking Skill (HOTS)}

Many theories have contributed vastly to the development of thinking. However, the introduction of Bloom's Taxonomy in 1956 is a breakthrough to domain-specific knowledge in higher forms of thinking in education. Three domains of educational activities identified are cognition, affective and psychomotor. The cognitive domain consists of six major categories in the order of difficulty with the lower order forms the foundation for the higher order (Bloom et al., 1956; Kauchak \& Eggen, 1998). The higher-order categories are application, analysis, synthesis and evaluation. This taxonomy was revisited and revised by Anderson and Krathwohl (2001). The categories which were in noun form were converted to verb form and rearranged to reflect a more active form of thinking (Anderson et al., 2001). Therefore, the concept of higher order thinking skills has been variously defined, although these definitions, when compared, have some common elements.

King, Goodson and Rohani (2011) define higher-order thinking skills as skills which "include critical, logical, reflective, meta-cognitive, and creative thinking. They are activated when individuals encounter unfamiliar problems, uncertainties, questions, or dilemmas. Successful applications of the skills result in explanations, decisions, performances, and products that are valid within the context of available knowledge and experience and that promote continued growth in these and other intellectual skills" (p.1). Meanwhile, the Ministry of Education (2014) defines higher order thinking skills as "the ability to apply knowledge, skills and values in reasoning and making reflection to solve problems, make decision, innovate and capable of inventing something" (p. 7). The definitions by King et al. (2011) and the Ministry of Education (2014) seem to identify higher order thinking in terms of transfer, thinking skills, and of problem-solving.

Given the definitions of higher order thinking, how do we learn it? One approach in the literature adapted the idea of evolving dimensions of learning (King et al., 2011). It moves from constructs in the dimension of thinking (Marzano et al., 1988) to enhance the quality of teaching and learning by incorporating the teaching of thinking throughout all content area and provide direction for planning instruction of curriculum. The dimension of learning does not position the thinking skills in a hierarchy. Instead, it introduces a new perspective to analyse approaches to teaching thinking. It sets up flexible planning and learner-centred approach that permits teachers to concentrate on the acquisition of dynamic knowledge: knowledge to be learned, contextualizing knowledge and meaningful application of knowledge (King et al., 2011). The pedagogy emphasises the need to effectively use various models, strategies, techniques or tools to foster thinking skills (Gul et al., 2014). 


\section{Approaches to Instruct Thinking Skills}

Approaches to teaching thinking have been classified into three categories: process approach, content approach and infusion approach (Ennis, 1989). The process approach is also known as teaching of thinking where thinking is taught explicitly as a stand-alone course/subject (Barak \& Shakhman, 2008; King et al., 2011; Nurulhuda \& Md Nasir Ibrahim, 2013; Rajendran, 2013; Sukla \& Dungsungneon, 2016). Content approach or direct instruction suggests implicit teaching for thinking to be employed using methods and tools/techniques to enhance in-depth understanding of content (King et al., 2011). This approach is based on the view that certain cognitive activities are focused on the particular subject area and in-depth knowledge of the content area is necessary (Chambers, 1988). The infusion approach, on the other hand, promotes the growth of skillful thinking explicitly by infusing in and through every stage of content area instruction. Swartz, Fischer, and Parks (1998) opine that thinking and content throw light on each other when learnt concurrently. The rationale for this approach is that thinking cannot be taught in a vacuum and according to Sternberg (1987), knowledge without thinking entails absence of knowledge judgement, and thinking without knowledge entails thinking without substance. Lessons interlaced with explicit strategies for skillful thinking which encourage collaboration, thinking about thinking and thinking transfer, completes the infusion approach framework, for best results (Swartz \& Parks, 1994).

\section{What is higher-order thinking skill (HOTS) in science teaching?}

Central to science teaching and learning approach in the science curriculum is the mastery of scientific skills, which comprise process skills, manipulative skills and thinking skills. Process skill, core to inquiry-oriented science education activates the cognitive process to think critically, creatively, analytically and systematically. HOTS pattern in science process skill includes observing, classifying, measuring using numbers, inferring, predicting, communicating, using space-time relationship, interpreting data, defining operationally, controlling variables, hypothesising and experimenting (Curriculum Development Centre, 2003). Based on the thinking skill model proposed, thinking skills comprise critical thinking and creative thinking when interlaced with reasoning results in HOTS such as conceptualising, decision making and problem-solving.

In Malaysian Science curriculum, infusion approach is recommended. Various stages of science lessons are infused with scientific and thinking skills explicitly (Curriculum Development Centre, 2003). The teacher takes the role of a facilitator or mediator to guide the students to apply these skills to solve particular problem independently. Among the recommended teaching practices in a learner-centred science environment are mastery learning, inquiry learning and activities that build and enhance science process skills, thinking skills and meta-cognition with the integration of information and communication technology. Therefore, teachers not only should have extensive knowledge of methods, activities and techniques befitting the stages of science lessons but also should be confident to put them into practice to foster HOTS successfully.

\section{The Need to Investigate Teachers' Motivation and Self-efficacy in Fostering HOTS in Science Lesson}

Literature acknowledges that besides teachers' perceptions of teaching and learning, their beliefs about knowledge and intelligence influences the style of instruction (King et al., 2011; 
Muhammad Ahmad Assaf, 2009; Nurulhuda \& Md Nasir Ibrahim, 2013; Rajendran, 2013). Lessons that promote HOTS need to be deliberately designed using various methods, activities and techniques according to the complexity of the task. Rehearsal strategies for complex task need to be taught first, followed by practice to strengthen procedural knowledge as well as providing individualised options (King et al., 2011). In this process-oriented, active-learning environment, transformation of teachers' role as facilitators, mediators or mentors is necessary. A lesson of this magnitude requires a vast knowledge of the teaching strategies and confidence combined with massive effort to put them into practice. Therefore, only teachers with high motivation and self-efficacy would be able to foster HOTS effectively.

There is a big percentage of in-service teachers who had their pre-service training in the 80s and 90 s where the thinking literature was at a young age. These teachers need to undergo quality training so that they could acquire the behaviour that can act as 'tools' to enhance the cognitive growth (Muhammad Ahmad Assaf, 2009). The 'tools' refer to the whole range of tested methods, activities and techniques to foster HOTS. Teaching for thinking will only succeed if teachers are confident and believe that they are capable of choosing and implementing these 'tools' effectively. In the other words, effective transfer of training depends on the amount of motivation and selfefficacy belief a teacher has. Furthermore, persistent and purposeful practice of higher-order teaching strategies can bring about positive results which in turn motivate the teachers to increase further the frequency of the 'tools' being put into practice.

Numerous literatures have also explored the effectiveness of the specific HOTS strategies used, as well as the motivation of the students in the classroom. Nonetheless, these studies have not explored the motivation and self-efficacy of teachers explicitly in using the 'tools' to foster HOTS in their science classroom practice. With this notion in mind, we designed this study to explore science teachers' motivation and self-efficacy about fostering HOTS in science teaching.

\section{METHODOLOGY}

The present study employed a survey method using a questionnaire to collect data. The sample involves in-service lower secondary science teachers in Peninsular Malaysia. Lower secondary represents a crucial transition for science education. During this period, the essential conceptual foundation for learning science needs to be established so that students can make important decision about their future direction of their science education in high school. It is at this point that many students begin to lose interest and develop the view that science is too difficult (Penny, 2003). The sample was selected using multi-stage random sampling technique involving four states, 29 districts and 152 schools. A cover letter, the questionnaire and a stamp attached return envelope were mailed to the selected schools. After employing follow-up procedures (facsimile reminders, calls and incentives), 231 questionnaires with a response rate of $62 \%$ were returned. Excluding missing data, only 220 were used for data analysis. The data were analysed using descriptive statistics of percentage, frequency, mean for the data on work motivation and standard deviation and inferential statistics using the correlation analysis. The SPSS version 21 was used for statistical analysis. 


\section{Instrument}

The instrument is a questionnaire entitled 'Training Needs Assessment of In-Service Teachers to Foster HOTS in Science Teaching' developed together with a group of seven researchers working on a bigger related project and was administered with permission. It was constructed based on information gleaned from the literature using document analysis and expert inputs. The face and content validity were established by five experts in the field.

The first section consists of demographic information and professional components such as gender, age, academic qualification, specialisation, education qualification, years of science teaching experience and training exposure. The second section consists of 33 items on instructional methods, activities, and techniques used in fostering HOTS: seven items for methods, 13 items for activities and 13 items for techniques. For this research, teaching methods are organised, orderly, systematic, and well-planned procedures for facilitating learning with specific labels attached such as Problembased Learning, Thinking-based Learning, Inquiry Learning, etc. Activities on the other hand, refer to more general acts of teaching and learning such as discussion, group work, debate, etc. Technique is a well-defined step-by-step procedure or a particular style for completing a specific task such as predict-observe-explain, think-pair-share, focused listing, KWL, etc. The items were either tested on work motivation or self-efficacy. Work motivation includes knowledge and importance, as discussed by Deci and Ryan, while self-efficacy includes perceived confidence and practice. Teachers' knowledge refers to meta-strategic knowledge defined as the explicit knowledge regarding the thinking strategies used in instruction (Zohar, 2006). It was measured on a 2-point scale: Yes, I know/No, I don't know. The response on the dimension on teachers' perceived importance (e.g. I believe the instructional method/activity/technique is important to foster HOTS), perceived confidence (e.g. I believe my confidence level in using the instructional method/activity/technique is ...) and practice (e.g. the frequency I put this instructional method/activity/technique into practice is ...) were given on 5-point Likert scale.

A pilot-test was carried out with 29 respondents. The Cronbach's Alpha coefficients ranged from 0.933 to 0.967 , suggesting a very good internal consistency reliability (Pallant, 2010).

\section{RESULTS}

The frequencies, percentages, means and standard deviations were computed for the variables: 33 methods/activities/techniques $(n=33)$ in terms of the participants' self-perceived knowledge, importance, practice and confidence in fostering HOTS. The correlation coefficients were also computed between perceived importance, level of confidence and frequency of practice.

Descriptive analysis on demography of the participants can be summarised as below: Gender; $17.3 \%$ male, $82.7 \%$ female. Professional qualification; $60.5 \%$ degree, $24.5 \%$ diploma, $6.8 \%$ teaching certificates, $8.2 \%$ others. Numbers of years of teaching science; $0.5 \%<1$ year, $14.5 \% 1-5$ years, 33.6\% 6-10 years, 26.4\% $11-15$ years, $15.0 \% 16-20$ years, $8.6 \% 21-30$ years, $1.8 \%>30$ years. Area of specialisation: Science $13.6 \%$, Physics, Biology, Chemistry $18.0 \%$, others $68.4 \%$.

Detailed descriptive statistics of variables to specific methods, activities, and techniques of fostering HOTS are given in Table 1. The Likert scale in the table are interpreted as 0.00-1.00 Low, 1.01-2.00 Moderately Low, 2.01-3.00 Moderate, 3.01-4.00 Moderately High and 4.01-5.00 High. 
Firstly, the absences of meta-strategic knowledge of fostering HOTS among respondents $(\mathrm{N}=220)$ are given in frequencies and percentages. Based on Table 1, it is noted that the percentages of participants who self-perceived that they do not have any meta-strategic knowledge on the methods, activities, and techniques range from $3.2 \%$ to $43.6 \%$, indicating that the absences of the meta-strategic knowledge of fostering HOTS exists across all the 31 variables: 7 methods, 13 activities and 13 techniques.

By identifying the instructional strategies in terms of methods, activities, and techniques of fostering HOTS with more than $10 \%$ of the respondents self-perceived that they do not have any knowledge, the methods of using Conceptual change and Analogy registered a percentage of $24.5 \%$ and $10.5 \%$ respectively, the activity of Designing model/prototype registered a percentage of $10.5 \%$, and the techniques of De Bono's Lateral Thinking, Six Thinking Hats, Think-Pair-Share, PredictObserve-Explain, 4W1H, Graphic organizers, and Habits of Mind registered a percentage of $43.6 \%$, $40.6 \%, 31.8 \%, 26.4 \%, 24.1 \%, 12.3 \%$, and $11.8 \%$ respectively.

Secondly, the means for self-perceived importance of the instructional methods, activities and techniques to foster HOTS range from 3.63 to 4.23 with an overall mean of 3.95 for methods, from 3.21 to 4.54 with an overall mean of 3.98 for activities, and from 3.59 to 4.46 with an overall mean of 3.99 for techniques. Therefore, the mean for self-perceived importance of the instructional strategies (i.e., methods, activities, and techniques) to foster HOTS is 3.97, indicating a moderately high level of importance.

Thirdly, the means for self-perceived practice of the instructional methods, activities and techniques to foster HOTS range from 2.59 to 3.53 with an overall mean of 3.09 for methods, from 2.22 to 4.29 with an overall mean of 3.27 for activities, and from 2.55 to 4.18 with an overall mean of 3.31 for techniques. Therefore, the mean for self-perceived practice of the instructional strategies (i.e., methods, activities, and techniques) to foster HOTS is 3.22, indicating a moderately high level of practice.

Fourthly, the means for self-perceived confidence in employing the instructional methods, activities and techniques to foster HOTS range from 3.20 to 3.76 with an overall mean of 3.53 for methods, from 2.92 to 4.29 with an overall mean of 3.67 for activities, and from 3.06 to 4.18 with an overall mean of 3.58 for techniques. Therefore, the mean for self-perceived confidence of employing the instructional strategies (i.e., methods, activities, and techniques) to foster HOTS is 3.59 , indicating a moderately high level of confidence. 
INTERNATIONAL JOURNAL OF ACADEMIC RESEARCH IN BUSINESS AND SOCIAL SCIENCES Vol. 8, No. 12, Dec, 2018, E-ISSN: 2222-6990 @ 2018 HRMARS

Table 1. Frequency, Percentage, Mean and Standard Deviation

\begin{tabular}{|c|c|c|c|c|c|c|c|c|c|c|c|c|c|}
\hline \multirow{2}{*}{ Type } & \multirow{2}{*}{ Item } & \multirow{2}{*}{$\begin{array}{l}\text { Methods/ } \\
\text { Activities/ } \\
\text { Techniques }\end{array}$} & \multicolumn{2}{|c|}{$\begin{array}{c}\text { No } \\
\text { Knowledge }\end{array}$} & \multicolumn{3}{|c|}{ Importance } & \multicolumn{3}{|c|}{ Practice } & \multicolumn{3}{|c|}{ Confidence } \\
\hline & & & $\begin{array}{c}\text { Fre } \\
q\end{array}$ & $\%$ & $\mathrm{~N}$ & $\begin{array}{c}\text { Mea } \\
\mathrm{n}\end{array}$ & s.d. & $\mathrm{N}$ & $\begin{array}{c}\text { Mea } \\
\mathrm{n}\end{array}$ & s.d. & $\mathrm{N}$ & $\begin{array}{c}\text { Mea } \\
\mathrm{n}\end{array}$ & s.d. \\
\hline \multirow{7}{*}{ 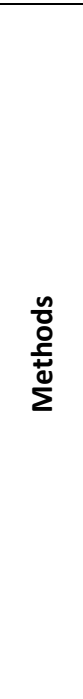 } & 1 & $\begin{array}{l}\text { Inquiry } \\
\text { learning }\end{array}$ & 9 & 4.1 & $\begin{array}{c}21 \\
1\end{array}$ & 4.23 & $\begin{array}{c}.60 \\
8\end{array}$ & 211 & 3.41 & $\begin{array}{c}.68 \\
5\end{array}$ & 209 & 3.76 & $\begin{array}{c}.84 \\
0\end{array}$ \\
\hline & 2 & $\begin{array}{l}\text { Problem- } \\
\text { based learning }\end{array}$ & 7 & 3.2 & $\begin{array}{c}21 \\
3\end{array}$ & 4.07 & $\begin{array}{c}.61 \\
1\end{array}$ & 211 & 3.23 & $\begin{array}{c}.82 \\
7\end{array}$ & 213 & 3.64 & $\begin{array}{c}.72 \\
3\end{array}$ \\
\hline & 3 & $\begin{array}{l}\text { Project-based } \\
\text { learning }\end{array}$ & 12 & 5.5 & $\begin{array}{c}20 \\
8 \\
\end{array}$ & 3.75 & $\begin{array}{c}.74 \\
5\end{array}$ & 206 & 2.63 & $\begin{array}{c}2.6 \\
3\end{array}$ & 208 & 3.34 & $\begin{array}{c}.84 \\
2\end{array}$ \\
\hline & 4 & $\begin{array}{l}\text { Thinking- } \\
\text { based learning }\end{array}$ & 12 & 5.5 & $\begin{array}{c}20 \\
7\end{array}$ & 4.25 & $\begin{array}{c}.56 \\
8\end{array}$ & 205 & 3.53 & $\begin{array}{c}.83 \\
2\end{array}$ & 207 & 3.76 & $\begin{array}{c}.73 \\
5\end{array}$ \\
\hline & 5 & Case study & 18 & 8.2 & $\begin{array}{c}20 \\
1\end{array}$ & 3.63 & $\begin{array}{c}.76 \\
5\end{array}$ & 199 & 2.59 & $\begin{array}{c}1.0 \\
3\end{array}$ & 201 & 3.20 & $\begin{array}{c}.88 \\
3\end{array}$ \\
\hline & 6 & Analogy & 23 & 10.5 & $\begin{array}{c}19 \\
8\end{array}$ & 3.99 & $\begin{array}{c}.72 \\
3\end{array}$ & 196 & 3.24 & $\begin{array}{c}.87 \\
0\end{array}$ & 198 & 3.62 & $\begin{array}{c}.72 \\
9\end{array}$ \\
\hline & 7 & $\begin{array}{l}\text { Conceptual } \\
\text { Change }\end{array}$ & 54 & 24.5 & $\begin{array}{c}16 \\
4\end{array}$ & 3.73 & $\begin{array}{c}.73 \\
6\end{array}$ & 162 & 2.99 & $\begin{array}{c}.95 \\
9\end{array}$ & 164 & 3.37 & $\begin{array}{c}.80 \\
0\end{array}$ \\
\hline \multicolumn{3}{|c|}{$\begin{array}{l}\text { Overall mean for HOTS } \\
\text { methods }\end{array}$} & & & & 3.95 & & & 3.09 & & & 3.53 & \\
\hline \multirow{9}{*}{ 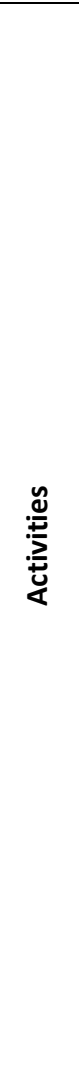 } & 8 & Questioning & 7 & 3.2 & $\begin{array}{c}21 \\
4\end{array}$ & 4.54 & $\begin{array}{c}.61 \\
0\end{array}$ & 212 & 4.29 & $\begin{array}{c}.84 \\
3\end{array}$ & 214 & 4.29 & $\begin{array}{c}.71 \\
1\end{array}$ \\
\hline & 32 & $\begin{array}{l}\text { Designing } \\
\text { model/ } \\
\text { prototype }\end{array}$ & 23 & 10.5 & $\begin{array}{c}19 \\
6\end{array}$ & 3.72 & $\begin{array}{c}.88 \\
6\end{array}$ & 194 & 2.78 & $\begin{array}{c}1.0 \\
5\end{array}$ & 196 & 3.36 & $\begin{array}{c}.93 \\
7\end{array}$ \\
\hline & 33 & $\begin{array}{l}75 \% \text { HOTS } \\
\text { test } \\
\text { questions }\end{array}$ & 13 & 5.9 & $\begin{array}{c}20 \\
7\end{array}$ & 3.94 & $\begin{array}{c}.80 \\
4\end{array}$ & 205 & 3.24 & $\begin{array}{c}.97 \\
5\end{array}$ & 207 & 3.59 & $\begin{array}{c}.81 \\
8\end{array}$ \\
\hline & 12 & $\begin{array}{l}\text { Scientific } \\
\text { investigation }\end{array}$ & 8 & 3.6 & $\begin{array}{c}21 \\
2\end{array}$ & 4.25 & $\begin{array}{c}.62 \\
4\end{array}$ & 210 & 3.69 & $\begin{array}{c}.81 \\
0\end{array}$ & 212 & 3.99 & $\begin{array}{c}.67 \\
4\end{array}$ \\
\hline & 13 & $\begin{array}{l}\text { Carrying out } \\
\text { experiment }\end{array}$ & 9 & 4.1 & $\begin{array}{c}21 \\
1 \\
\end{array}$ & 4.41 & $\begin{array}{c}.58 \\
1 \\
\end{array}$ & 209 & 3.86 & $\begin{array}{c}.78 \\
4 \\
\end{array}$ & 211 & 4.13 & $\begin{array}{c}.60 \\
0 \\
\end{array}$ \\
\hline & 14 & $\begin{array}{l}\text { Hands-on \& } \\
\text { Minds-on }\end{array}$ & 9 & 4.1 & $\begin{array}{c}21 \\
1\end{array}$ & 4.29 & $\begin{array}{c}.59 \\
3\end{array}$ & 209 & 3.77 & $\begin{array}{c}.77 \\
1\end{array}$ & 211 & 3.98 & $\begin{array}{c}.65 \\
4\end{array}$ \\
\hline & 15 & $\begin{array}{l}\text { Problem } \\
\text { solving }\end{array}$ & 8 & 3.6 & $\begin{array}{c}21 \\
2\end{array}$ & 4.18 & $\begin{array}{c}.58 \\
3\end{array}$ & 210 & 3.58 & $\begin{array}{l}.81 \\
6\end{array}$ & 212 & 3.81 & $\begin{array}{c}.73 \\
2\end{array}$ \\
\hline & 16 & $\begin{array}{l}\text { Group } \\
\text { discussion }\end{array}$ & 8 & 3.6 & $\begin{array}{c}21 \\
2\end{array}$ & 4.15 & $\begin{array}{c}.65 \\
7\end{array}$ & 210 & 3.61 & $\begin{array}{c}.87 \\
4\end{array}$ & 212 & 3.89 & $\begin{array}{c}.72 \\
4\end{array}$ \\
\hline & 17 & $\begin{array}{l}\text { Critical } \\
\text { evaluation of } \\
\text { other } \\
\text { students' } \\
\text { work }\end{array}$ & 12 & 5.5 & $\begin{array}{c}20 \\
8\end{array}$ & 3.84 & $\begin{array}{c}.72 \\
2\end{array}$ & 206 & 2.96 & $\begin{array}{c}.98 \\
2\end{array}$ & 208 & 3.51 & $\begin{array}{c}.80 \\
5\end{array}$ \\
\hline
\end{tabular}


INTERNATIONAL JOURNAL OF ACADEMIC RESEARCH IN BUSINESS AND SOCIAL SCIENCES Vol. 8, No. 12, Dec, 2018, E-ISSN: 2222-6990 @ 2018 HRMARS

\begin{tabular}{|c|c|c|c|c|c|c|c|c|c|c|c|c|c|}
\hline & 18 & $\begin{array}{l}\text { Challenging } \\
\text { teacher's/ } \\
\text { peers' ideas }\end{array}$ & 13 & 5.9 & $\begin{array}{c}20 \\
7\end{array}$ & 3.70 & $\begin{array}{c}.79 \\
9\end{array}$ & 205 & 2.76 & $\begin{array}{c}.99 \\
3\end{array}$ & 207 & 3.32 & $\begin{array}{c}.86 \\
2\end{array}$ \\
\hline & 19 & $\begin{array}{l}\text { Critical } \\
\text { reviews }\end{array}$ & 19 & 8.6 & $\begin{array}{c}20 \\
1 \\
\end{array}$ & 3.54 & $\begin{array}{c}.91 \\
1 \\
\end{array}$ & 199 & 2.62 & $\begin{array}{c}1.0 \\
3 \\
\end{array}$ & 201 & 3.22 & $\begin{array}{c}.91 \\
9 \\
\end{array}$ \\
\hline & 20 & $\begin{array}{l}\text { Group } \\
\text { presentation } \\
\mathrm{s}\end{array}$ & 8 & 3.6 & $\begin{array}{c}21 \\
2 \\
\end{array}$ & 3.92 & $\begin{array}{c}.71 \\
8\end{array}$ & 210 & 3.16 & $\begin{array}{c}.91 \\
9\end{array}$ & 212 & 3.64 & $\begin{array}{c}.80 \\
5\end{array}$ \\
\hline & 21 & Debates & 18 & 8.2 & $\begin{array}{c}20 \\
2\end{array}$ & 3.21 & $\begin{array}{c}.93 \\
5\end{array}$ & 200 & 2.22 & $\begin{array}{c}.99 \\
2\end{array}$ & 202 & 2.92 & $\begin{array}{c}.95 \\
6\end{array}$ \\
\hline & $\begin{array}{r}\text { rall m } \\
\text { act }\end{array}$ & $\begin{array}{l}\text { for HOTS } \\
\text { ies }\end{array}$ & & & & 3.98 & & & 3.27 & & & 3.67 & \\
\hline \multirow{13}{*}{ 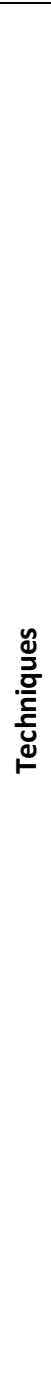 } & 9 & Prompting & 6 & 2.7 & $\begin{array}{c}21 \\
4 \\
\end{array}$ & 4.46 & $\begin{array}{c}.58 \\
6 \\
\end{array}$ & 212 & 4.18 & $\begin{array}{c}.74 \\
7 \\
\end{array}$ & 213 & 4.18 & $\begin{array}{c}.72 \\
2 \\
\end{array}$ \\
\hline & 10 & $\begin{array}{l}\text { HOTS } \\
\text { questioning }\end{array}$ & 7 & 3.2 & $\begin{array}{c}21 \\
3 \\
\end{array}$ & 4.28 & $\begin{array}{c}.63 \\
9 \\
\end{array}$ & 211 & 3.73 & $\begin{array}{c}.76 \\
2 \\
\end{array}$ & 213 & 3.81 & $\begin{array}{c}.72 \\
2 \\
\end{array}$ \\
\hline & 11 & $\begin{array}{l}\text { Reflective } \\
\text { questioning }\end{array}$ & 20 & 9.1 & $\begin{array}{c}20 \\
0 \\
\end{array}$ & 3.94 & $\begin{array}{c}.78 \\
1 \\
\end{array}$ & 198 & 3.29 & $\begin{array}{c}.96 \\
9 \\
\end{array}$ & 200 & 3.58 & $\begin{array}{c}.80 \\
5 \\
\end{array}$ \\
\hline & 22 & $\begin{array}{l}\text { Identifying } \\
\text { HOTS }\end{array}$ & 10 & 4.5 & $\begin{array}{c}21 \\
0\end{array}$ & 4.08 & $\begin{array}{c}.68 \\
7\end{array}$ & 208 & 3.48 & $\begin{array}{c}.87 \\
9\end{array}$ & 210 & 3.71 & $\begin{array}{c}.71 \\
6\end{array}$ \\
\hline & 23 & $\begin{array}{l}\text { Thinking } \\
\text { tools }\end{array}$ & 9 & 4.1 & $\begin{array}{c}21 \\
1 \\
\end{array}$ & 4.11 & $\begin{array}{c}.65 \\
9 \\
\end{array}$ & 209 & 3.67 & $\begin{array}{c}.77 \\
3 \\
\end{array}$ & 211 & 3.86 & $\begin{array}{c}.71 \\
6 \\
\end{array}$ \\
\hline & 24 & $\begin{array}{l}\text { Graphic } \\
\text { organisers }\end{array}$ & 27 & 12.3 & $\begin{array}{c}19 \\
3 \\
\end{array}$ & 3.93 & $\begin{array}{c}.76 \\
7 \\
\end{array}$ & 191 & 3.11 & $\begin{array}{c}1.0 \\
2 \\
\end{array}$ & 193 & 3.49 & $\begin{array}{c}.91 \\
4 \\
\end{array}$ \\
\hline & 25 & $\begin{array}{l}\text { Lateral } \\
\text { thinking }\end{array}$ & 96 & 43.6 & $\begin{array}{c}12 \\
4\end{array}$ & 3.67 & $\begin{array}{c}.74 \\
0\end{array}$ & 122 & 2.66 & $\begin{array}{c}.97 \\
7\end{array}$ & 124 & 3.06 & $\begin{array}{c}.81 \\
4\end{array}$ \\
\hline & 26 & $\begin{array}{l}\text { Six Thinking } \\
\text { Hats }\end{array}$ & 90 & 40.6 & $\begin{array}{c}13 \\
0\end{array}$ & 3.59 & $\begin{array}{c}.82 \\
3 \\
\end{array}$ & 128 & 2.55 & $\begin{array}{c}. \\
.97 \\
9\end{array}$ & 130 & 3.11 & $\begin{array}{c}.87 \\
4 \\
\end{array}$ \\
\hline & 27 & $4 \mathrm{~W} 1 \mathrm{H}$ & 53 & 24.1 & $\begin{array}{c}16 \\
7\end{array}$ & 3.95 & $\begin{array}{c}.84 \\
9\end{array}$ & 165 & 3.32 & $\begin{array}{c}1.0 \\
5\end{array}$ & 167 & 3.56 & $\begin{array}{c}.90 \\
9\end{array}$ \\
\hline & 28 & $\begin{array}{l}\text { Think-Pair- } \\
\text { Share }\end{array}$ & 70 & 31.8 & $\begin{array}{c}15 \\
0\end{array}$ & 3.80 & $\begin{array}{c}.72 \\
4\end{array}$ & 148 & 2.94 & $\begin{array}{c}.93 \\
5\end{array}$ & 150 & 3.33 & $\begin{array}{c}.85 \\
5\end{array}$ \\
\hline & 29 & POE & 58 & 26.4 & $\begin{array}{c}16 \\
2 \\
\end{array}$ & 3.92 & $\begin{array}{c}.69 \\
6 \\
\end{array}$ & 160 & 3.06 & $\begin{array}{c}.99 \\
5 \\
\end{array}$ & 162 & 3.43 & $\begin{array}{l}.87 \\
7 \\
\end{array}$ \\
\hline & 30 & $\begin{array}{l}\text { Thinking } \\
\text { language }\end{array}$ & 13 & 5.9 & $\begin{array}{c}20 \\
7\end{array}$ & 4.09 & $\begin{array}{l}.70 \\
8\end{array}$ & 205 & 3.57 & $\begin{array}{c}.90 \\
3\end{array}$ & 207 & 3.79 & $\begin{array}{l}.76 \\
3\end{array}$ \\
\hline & 31 & $\begin{array}{l}\text { Habits of } \\
\text { Mind }\end{array}$ & 26 & 11.8 & $\begin{array}{c}19 \\
4\end{array}$ & 4.02 & $\begin{array}{c}.79 \\
5\end{array}$ & 192 & 3.46 & $\begin{array}{c}.99 \\
1\end{array}$ & 194 & 3.63 & $\begin{array}{l}.86 \\
7\end{array}$ \\
\hline \multicolumn{3}{|c|}{$\begin{array}{l}\text { Overall mean for HOTS } \\
\text { techniques }\end{array}$} & & & & 3.99 & & & 3.31 & & & 3.58 & \\
\hline
\end{tabular}


Finally, as seen from the Table 2, the mean for the Likert scale on perception of importance was $3.97(n=33, s d=.29)$, for frequency of practice was $3.22(n=33, s d=.49)$ and for overall confidence was $3.59(n=33, s d=.33)$.

Analysis of Spearman correlation test shows a significantly weak positive relationship between importance and practice $(r=.32, p<.05)$ (Cohen, 1988). However, a weak relationship may exist in the sample by chance or may be due to measurement or sampling error. Similarly, importance has a significantly weak positive relationship with confidence $(r=.49, p<.05)$. Thus, the perceived level of importance amongst the science teachers is significantly related to the frequency of practice and the level of confidence although the relationships are weak. On the contrary, Spearman's correlation test indicates an existence of a significantly strong relationship between practice and confidence $(r=64$, $p<.05$ ) (Cohen, 1988). Thus, the teachers appear to practise the methods/activities/techniques more when they have a higher level of confidence.

Table 2. Means, Standard Deviations and Correlations

\begin{tabular}{lcccccc}
\hline \multicolumn{1}{c}{ Variables } & $\mathrm{n}$ & $\overline{\boldsymbol{X}}$ & $\mathrm{sd}$ & $(1)$ & $(2)$ & $(3)$ \\
\hline 1. Importance & 33 & 3.97 & .29 & - & & \\
2. Practice & 33 & 3.22 & .49 & $.32^{* *}$ & - & \\
3. Confidence & 33 & 3.59 & .33 & $.49^{* *}$ & $.64^{* *}$ & - \\
\hline
\end{tabular}

$* * p<.05$ (2-tailed)

\section{DISCUSSION}

The participants of this study displayed moderately high levels of importance, practice and confidence, indicating that in-service lower secondary science teachers tended to perceive themselves as motivated and efficacious in fostering HOTS. It has been observed that teachers' perception of importance on instructional methods to foster HOTS is at the higher end of the 'moderately high' range. However, the frequencies or magnitude and strength of putting them into practice are at the lower end of the 'moderately high' range. The perceived level of confidence, meanwhile, lies in the middle position of the 'moderately high' range. A similar pattern of perception is also seen for instructional activities and techniques.

Investigation of the relationships between the level of importance, frequency of practice and level of confidence displays significant correlations between each other. A high level of importance indicates higher frequency of practice, which in turn increases the confidence level of teachers. This finding is consistent with Bandura's Social Cognitive Theory (Bandura, 1986) and previous research finding by Chowdhury and Shahabuddin (2007), that states that self-efficacy increases with the increase in the frequency of practice.

Regarding meta-strategic knowledge on fostering HOTS in science teaching, this study shows that teachers lack knowledge in instructional techniques which entail the specific step by step instructions. The absence of this meta-strategic knowledge particularly for Project-based learning, case study, designing model/prototype, graphic organisers, de Bono's Lateral Thinking, Six Thinking Hats, 4W1H, Think-Pair-Share and Predict-Observe-Explain affects teachers practice which falls into the 'moderately low' range for these particular methods/activities/techniques. The lack of knowledge 
has practical implications for school administrators and the ministry. More professional development agenda needs to be made available to teachers to enhance their knowledge and skills of fostering HOTS that must reach a certain level of confidence to ensure teachers practice them in class. However, the principles of subjecting teachers to training courses and workshops have to be carefully observed as the first principle to successful training is to ensure teachers selected are receptive and motivated to undergo the training (Muhammad Zahid Iqbal \& Rashid Ahmad Khan, 2011). If the results of TIMSS and PISA are used for benchmarking students' level of cognitive thinking, years of practice and training teachers seem to deliver minimal results in building and enhancing teachers' knowledge and skills in fostering HOTS. The most recent result of PISA (Kementerian Pendidikan Malaysia, 2013b) places Malaysia at the bottom one-third among 72 participating countries worldwide. This trend has been the norm of TIMSS since 2003.

\section{CONCLUSION}

This study affirms in-service science teachers' motivation and self-efficacy are moderately high and significantly related to fostering HOTS. The quality of science teaching can be predicted by an examination of the science teachers' motivation and self-efficacy in fostering HOTS in contemporary schooling. In-service teachers' meta-strategic knowledge and perceived importance of this metastrategic knowledge in fostering HOTS, contribute positively to shaping their motivation and further promoting self-efficacy. Therefore, any form of formal training program for in-service teachers should assist them to acquire and emphasize the importance of meta-strategic knowledge. Other than that, it is necessary for the teachers to enhance their HOTS if they are expected to foster HOTS in their teaching practice. According to Gul et al. (2014), it is reasonable to expect an increase in the level of motivation among in-service teachers as they progress through training. This provides them more autonomous opportunities in the choice of methods, activities and techniques for their classroom practice.

The limitation of this study is that motivation and self-efficacy belief is considered as domainspecific and it covers a very narrow scope; meta-strategic knowledge of fostering HOTS and importance is used to represent motivation whereas frequency of practice and confidence in fostering HOTS are used to represent self-efficacy. According to Lent and Hackett (1987), overlyspecific assessment criteria have less practical value. However, this limitation can also be seen as a strength of this study since according to Bandura (1997), "self-efficacy beliefs should be measured in terms of particularized judgments of capability that may vary across realms of activity, different levels of task demands within a given activity domain, and under different situational circumstances" (p. 6). Thus, the nature of this study heeded the caution that self-efficacy should be assessed at the level of specificity that corresponds to the specific task in the domain being analysed (Pajares, 1997). This study is significant because it is a pioneer quantitative study on the motivation and self-efficacy of science teachers in peninsular Malaysia related to the knowledge and teaching of HOTS.

Another limitation is that, because of the survey nature of this study, self-efficacy is assessed in terms of teachers' self-reported practice and confidence rather than investigator-observed practice and confidence. The future scope should consider measurement methods such as performance-based assessment with longitudinal research design that would provide further insight 
INTERNATIONAL JOURNAL OF ACADEMIC RESEARCH IN BUSINESS AND SOCIAL SCIENCES

Vol. 8, No. 12, Dec, 2018, E-ISSN: 2222-6990 @ 2018 HRMARS

into understanding and conceptualising the belief system in fostering HOTS in science teaching. In addition, a wider measure such as job commitment, teachers' personal characteristics, and a wider range of motivation constructs to provide a better insight on intrinsic motivation, extrinsic motivation and self-efficacy.

\section{Acknowledgement}

We extend our gratitude to Ministry of Education Malaysia for providing the funds under the Fundamental Research Grant Scheme (FRGS): 2015-0169-107-02 and UPSI for providing the official approval that enable us to do the research. Special thanks to the teachers from the public schools in Malaysia for their participation in this research.

\section{REFERENCES}

Amabile, T. M. (1993). Motivational synergy: Toward new conceptualizations of intrinsic and extrinsic motivation in the workplace. Human Resource Management Review, 3(3), 185-201.

Anderson, L. W., \& Krathwohl, D. R. (2001). A Taxonomy for Learning, Teaching and Assessing: A Revision of Bloom's Taxonomy of Educational Objectives: Complete Edition. New York: Longman.

Anderson, L. W., Krathwohl, M. D., Airasian, P. W., Cruikshank, K. A., Mayer, R. E., Pintrich, P. R., Wittrock, M. C. (2001). Taxonomy for Learning, Teaching and Assessing: A Revision of Bloom's Taxonomy of Educational Objectives. New York: Pearson, Allyn and Bacon.

Bahagian Perkembangan Kurikulum. (2013). KBAT: Inisiatif Kemahiran Berfikir Aras Tinggi di Sekolah. Putrajaya, Malaysia: Kementerian Pendidikan Malaysia.

Bandura, A. (1986). Social Foundation of Thought and Action: A Social Cognitive Theory. New Jersey: Prentice-Hall Eaglewood Cliffs.

Bandura, A. (1997). Self-efficacy: The exercise of control. New York: Freeman \& Company.

Barak, M., \& Shakman, L. (2008). Fostering higher order thinking skill in science class: teachers' reflections. Teachers and Teaching: Theory and Practice, 14(3), 191-208. http://doi.org/10.1080/13540600802006079

Bedel, E. F. (2015). Exploring Academic Motivation, Academic Self-efficacy and Attitudes toward Teaching in Pre-service Early Childhood Education Teachers. Journal of Education and Training Studies, 4(1), 142-149. http://doi.org/10.11114/jets.v4i1.561

Bloom, B. S., Engelhart, M. D., Frust, E. J., Hill, W. H., \& Krathwohl, D. R. (1956). Taxonomy of Educational Objectives, Handbook I: The Cognitive Domain. New York: David Mc Kay Co. Inc.

Bostan, M. I., Sahin, E., \& Ertepinar, H. (2015). Teacher beliefs towards using alternative teaching approaches in Science \& Mathematics classes related to experiences in teaching. International Journal of Environment \& Science Education, 10(5), 603-621.

Brophy, J. (2010). Motivating Students to Learn (3rd ed). New York, NY: Routledge.

Bruner, J. S. (1966). Toward a Theory of Instruction, Cambridge, Mass.: Belkapp Press

Chambers, J. (1988). Teaching thinking throughout the curriculum - Where else? Educational Leadership, 45(7), 4-6.

Chinedu, C. C., Kamin, Y., \& Olabiyi, O. S. (2015). Strategies for improving higher order thinking skills in teaching and learning of design and technology education. Journal of Technical Education and Training, 7(2), 35-43. 
INTERNATIONAL JOURNAL OF ACADEMIC RESEARCH IN BUSINESS AND SOCIAL SCIENCES

Vol. 8, No. 12, Dec, 2018, E-ISSN: 2222-6990 @ 2018 HRMARS

Chowdhury, M. S., \& Shahabuddin, A. M. (2007). Self-efficacy, motivation and their relationship to academic performance of Bangladesh college students. College Quarterly, 10(1), 1-9.

Curriculum Development Center. (2003). Science Syllabus 2003. Putrajaya, Malaysia: Curriculum Development Centre.

Curriculum Development Centre. (2005). Integrated Curriculum for Secondary Schools: Curriculum Specifications Science Form 4. Putrajaya: Curriculum Development Centre.

Deci, E. L. (1972). Intrinsic motivation, extrinsic reinforcement, and inequity. Journal of Personality and Social Psychology, 22(1), 113-120.

Deci, E. L., \& Ryan, R. M. (1985). Intrinsic Motivation and Self-Determination in Human Behavior. Boston, MA: Springer US. http://doi.org/10.1007/978-1-4899-2271-7

Ennis, R. H. (1989). Critical thinking and subject specificity: Clarification and needed research. Educational Researcher, 18(3), 4-10.

Goethals, P. L. (2013). The pursuits of higher order thinking in mathematics classrooms: A review. Retrieved from www.usma.edu/cfc/literature / Goethals_13pdf.

Gul, R. B., Khan, S., Ahmad, A., Cassum, C., Saeed, T., Parpia, Y. \& Proffeto-McGrath, J. (2014). Enhancing educators' skill for promoting critical thinking in their classroom discourses: $A$ randomized control trial. International Journal of Teaching and Learning in Higher Education, 26(1), 37-54. Retrieved from http://www.ised.org/ijtlhe.

Hase, S., \& Kenyon, C. (Eds.) (2015). Self-determined Learning: Heutagogy in Action. UK: Bloomsbury Academic.

Kauchak, D. P., \& Eggen, P. H. (1997). Learning and Teaching Methods. Boston, MA: Allyn and Bacon.

Kauchak, D. P., \& Eggen, P. D. (1998). Learning and Teaching: Research-based Methods (3rd ed.). Boston: Allyn and Bacon.

Kementerian Pendidikan Malaysia. (2013a). Pelan Pembangunan Pendidikan Malaysia 2013-2015

(Pendidikan prasekolah hingga lepas menengah). Putrajaya, Malaysia: Kementerian Pendidikan Malaysia.

Kementerian Pendidikan Malaysia. (2013b). Ringkasan Eksekutif Pelan Pembangunan Pendidikan Malaysia 2013-2025 (Pendidikan Prasekolah hingga Lepas Menengah). Retrieved from http://www.moe.gov.my/cms/upload_files/articlefile/2013/articlefile_file_003113.pdf

King, F.J., Goodson, L., \& Rohani, F. (2011). Higher Order Thinking Skills: Definition, Teaching Strategies, \& Assessment. Tallahasee, FL: Center for Advancement of Learning and Assessment, Florida State University.

Lens, W., Deci, E. L., Vansteenkiste, M. (2006). Intrinsic versus extrinsic goal contents in selfdetermination theory: Another look at the quality of academic motivation. Educational Psychologist, 4(1), 19-31. Retrieved from http://dx.doi.org/10.12071s15326985ep4101.4

Lent, R. W., \& Hackett, G. (1987). Career self-efficacy: Empirical status and future directions. Journal of Vocational Behavior, 30, 347-382.

Maddux, J. E. (1995). Self-efficacy theory. In J. E. Maddux (Ed.). Self-efficacy, Adaptation, and Adjustment: Theory, Research, and Application (pp. 281-303). New York, NY: Plenum Press. Marzano, R. J., Brande, R. S., Hughes, C. S., Jones, B. F., Presseisen, C. S., Rankin, S. C., \& Suhor, C. 
INTERNATIONAL JOURNAL OF ACADEMIC RESEARCH IN BUSINESS AND SOCIAL SCIENCES

Vol. 8, No. 12, Dec, 2018, E-ISSN: 2222-6990 @ 2018 HRMARS

(1988). Dimension of thinking: A Framework for Curriculum \& Instruction. Alexandria, VA: Association for Supervision and Curriculum Development.

Muhammad Ahmad Assaf. (2009). Teachers and Thinking: A Literature Review of the Teaching of

Thinking Skills. Washington, D.C.: ERIC Clearing House on Teaching and Teacher Education.

Retrieved from ERIC database. (ED505029)

Muhammad Zahid Iqbal, A., \& Rashid Ahmad Khan. (2011). The growing concept and uses of training needs assessment: A review with proposed model. Journal of European Industrial Training, 35(5), 439-466. http://doi.org/10.1108/03090591111138017

Nooraini Othman \& Khairul Azmi Mohamad (2014). Thinking skill education and transformational progress in Malaysia. International Education Studies, 7(4), 27-32. http://doi.org/10.5539/ies.v7n4p27

Nurulhuda, A. R., \& Md Nasir Ibrahim (Eds.). (2013). Pemikiran Kritis dan Kreatif: Konsep, Pendekatan dan Aplikasi dalam Pengajaran dan Pembelajaran. Tanjung Malim, Perak: Universiti Pendidikan Sultan Idris.

Pajares, F. (1997). Current directions in self-efficacy research. In M. Maehr \& P. R. Pintrich (Eds.), Advances in Motivation and Achievement (Volume 10, pp. 1749). Greenwich, CT: JAI Press

Pallant, J. (2010). SPSS Survival Manual: A Step by Step Guide to Data Analysis using SPSS (4th ed.). England: The McGraw-Hill Co.

Penny, K. (2003). The anatomy of Junior High School science textbook: An analysis of textual characterization and comparison to mehsa reports of science. Canadian Journal of Science, Mathematics and Technologies Education, 416-433. Retrieved from http://www.tandfonline.com/doi/pdf/...14926150309556580

Raisa, B. G., Khan, S., Ahmed, A., Cassum, S., Saeed, T., Parpio, Y., \& Porfetto-macgrath, J. (2014). Enhancing Educators' Skills for Promoting Critical Thinking in Their Classroom Discourses: A Randomised Control Trial, 26(1), 37-54. doi:10.7939/R3D50G17X

Rajendran, N. S. (2013). Teaching and acquiring higher-order thinking skills: Theory and practice. Tanjung Malim, Perak: Universiti Pendidikan Sultan Idris.

Ritter, J. M., Boone, W. J., \& Rubba, P. A. (2001). Development of an instrument to assess prospective elementary teacher self- efficacy beliefs about equitable science teaching and learning (SEBEST). Journal of Science Teacher Education, 12(3), 175-198.

Ryan, R. M., \& Deci, E. L. (2000). Self-determination theory and the facilitation of intrinsic motivation, social development, and well-being. American Psychologist, 55(1), 68-78.

Ryan, R. M., \& Stiller, J. (1991). The social contexts of internalization: Parent and teacher influences on autonomy, motivation and learning. In P.R. Pintrich and M. R. Maehr (Eds.), Advances in Motivation and Achievement. (Volume 7, pp 115-149). Greenwich City: JAI.

Scott, W. E., Farh, J. L., \& Podsakoff, P. M. (1988). The effects of 'intrinsic' and 'extrinsic' reinforcement contingencies on task behavior. Organizational Behavior and Human Decision Processes, 41(3), 405-425.

Stajkovic, A. (2016). Social cognitive theory and self- efficacy : Implications for motivation theory and practice. Social Cognitive Theory and Self . efficacy : Implications for Motivation Theory and Practice are, (March).

Stajkovic, A. D., \& Luthans, F. (1998). Self-efficacy and work-related performance: A meta-analysis. 
Psychological Bulletin, 124(2), 240-261. http://doi.org/10.1037/0033-2909.124.2.240

Sternberg, R.J. (1987). Questions and answers about the nature and teaching of thinking skills. In J. Baron \& R.J. Sternberg (Eds.), Teaching Thinking Skills: Theory and Practice, 252-259. New York: Freeman.

Sukla, D., \& Dungsungneon, A. P. (2016). Students Perceived Level and Teachers Teaching Strategies of Higher Order Thinking Skills: A Study on Higher Educational Institutions in Thailand, 7(12), 211-219.

Swartz, R., Fischer, S., \& Parks, S. (1998). Infusing the Teaching of Critical Thinking and Creative Thinking in Secondary Science: A Lesson Design Handbook. Pacific Grove, CA: Critical Thinking Books \& Software.

Swartz, R. J., \& Parks, S. (1994). Infusing the Teaching of Critical and Creative Thinking into Content Instruction. Pacific Grove, CA: Critical Thinking Books \& Software.

Vedder-Weiss, D., \& Fortus, D. (2013). School, teachers, peers, and parents' goals emphases and adolescents' motivation to learn science in and out of school. Journal of Research in Science Teaching, 50(8), 952-988.

Zohar, A. (2006). The nature and development of teachers' metastrategic knowledge in the context of teaching higher-order thinking. Journal of Learning Science, 15(3), 331-377. 